\title{
Variability of snail growing season at the Chinese Loess Plateau during the last $75 \mathrm{ka}$
}

\author{
HUANG LinPei ${ }^{1,2 *}$, WU NaiQin ${ }^{1}$, GU ZhaoYan ${ }^{1} \&$ CHEN XiaoYun ${ }^{1}$ \\ ${ }^{1}$ Key Laboratory of Cenozoic Geology and Environment, Institute of Geology and Geophysics, Chinese Academy of Sciences, \\ Beijing 100029, China; \\ ${ }^{2}$ Graduate University of Chinese Academy of Sciences, Beijing 100049, China
}

Received September 20, 2011; accepted November 25, 2011; published online December 30, 2011

\begin{abstract}
Knowledge of seasonal climate change is one of the key issues facing Quaternary paleoclimatic studies and estimating seasonal climate change is difficult, especially changes such as seasonal length on glacial-interglacial timescales. The stable isotope composition from seasonal land snail shells provides the potential to reveal seasonal climatic features. Two modern land snail species, cold-aridiphilous Pupilla aeoli and thermo-humidiphilous Punctum orphana, were collected from different climatic zones in 18 localities across the Chinese Loess Plateau, spanning 11 degrees of longitude and covering a range of $1000 \mathrm{~km}^{2}$. The duration of the snail growing season (temperature $\geqslant 10^{\circ} \mathrm{C}$ ) was shorter $(202 \pm 6 \mathrm{~d})$ in the eastern Loess Plateau compared with in the western Loess Plateau $(162 \pm 7 \mathrm{~d})$. The $\delta^{13} \mathrm{C}$ of $P$. aeoli shells was $-9.1 \%$ to $-4.7 \%$ and $-5.0 \%$ to $0.3 \%$ for $\delta^{18} \mathrm{O}$. For $P$. orphana, the $\delta^{13} \mathrm{C}$ ranged from $-9.1 \%$ o to $-1.9 \%$ and $-8.9 \%$ to $-2.9 \%$ or for $\delta^{18} \mathrm{O}$. Both the $\delta^{13} \mathrm{C}$ and $\delta^{18} \mathrm{O}$ differences between the two snail species were reduced from the east to the western Loess Plateau (2.8\%o to $0.2 \pm 1.1 \%$ ofor $\delta^{13} \mathrm{C}$ and $4.7 \%$ o to $2.9 \pm 1.3 \%$ of $\delta^{18} \mathrm{O}$ ). These isotopic differences roughly reflect the difference in the growing season lengths between the east and west Loess Plateau indicating that the duration of the snail growing season shortens by $15 \mathrm{~d}$ or $19 \mathrm{~d}$ if the difference decreases by $1 \% \circ$ in $\delta^{13} \mathrm{C}$ or $\delta^{18} \mathrm{O}$, respectively. Thus, the difference in $\delta^{13} \mathrm{C}$ and $\delta^{18} \mathrm{O}$ between both snail species can be used to reveal the length of the snail growing season in the past. Based on our investigation, the length of the snail growing seasons from the Xifeng region during the last $75 \mathrm{ka}$ was reconstructed. During the mid-Holocene $(8-3 \mathrm{ka})$, the mean isotopic difference from both snail species reached maximum values of $2.6 \pm 0.7 \%$ and $2.1 \pm 1.4 \%$ for $\delta^{13} \mathrm{C}$ and $\delta^{18} \mathrm{O}$, respectively. This was followed by MIS 3 that ranged from $2.5 \pm 0.4 \%$ for $\delta^{13} \mathrm{C}$ and $1.6 \pm 0.8 \%$ for $\delta^{18} \mathrm{O}$. The Last Glacial Maximum changed by only $0.2 \%$ and $0.4 \%$ for $\delta^{13} \mathrm{C}$ and $\delta^{18} \mathrm{O}$, respectively. Therefore, we estimate that the duration of the snail growing seasons to be $\sim 200 \pm 10 \mathrm{~d}$ during the mid-Holocene, $190 \pm 6 \mathrm{~d}$ in MIS 3 and $160 \pm 3 \mathrm{~d}$ during the last glacial period.
\end{abstract}

land snail, stable carbon and oxygen isotopes, last glacial, snail growing season, Xifeng loess sequence

Citation: Huang L P, Wu N Q, Gu Z Y, et al. Variability of snail growing season at the Chinese Loess Plateau during the last 75 ka. Chin Sci Bull, 2012, 57: 1036-1045, doi: 10.1007/s11434-011-4931-z

Milankovitch theory postulates that variations of the Earth's orbital parameters influences the distribution of heat between seasons and controlled climate changes during Quaternary glacial-interglacial (G-IG) cycles [1]. In other words, long-term climate change is governed by the variation of seasonality or seasonal length [2]. Knowing how seasonal lengths shifted during Quaternary G-IG cycles is an important key to further understanding the processes and

*Corresponding author (email: lphuang@mail.iggcas.ac.cn) mechanisms of long-term climate change.

Climate in the Chinese Loess Plateau is significantly controlled by the East Asian winter and summer monsoon, with distinct seasonal changes that can be divided into four seasons. These are based on a pentad-temperature method that is a mean value of per five-day temperature [3]. Temperatures lower than $10^{\circ} \mathrm{C}$ are attributed to winter and those over $22^{\circ} \mathrm{C}$ to summer. Pentad temperatures between $10^{\circ} \mathrm{C}$ and $22^{\circ} \mathrm{C}$ are either spring or autumn [3]. It is generally accepted that in the monsoon regions, the seasonal length 
and growing period of fauna and flora are mainly controlled by the intensity of the summer and winter monsoon [2]. Previous studies on paleoclimate of the Loess Plateau are based on physical and chemical indices, such as magnetic susceptibility [4-7], grain size [8,9] and FeD/FeT [10]. However, owing to the limitation of sensitivity, these proxies only indicate variation in long-term climate and cannot clarify features such as seasonal climate change. Thus, finding a reliable proxy for seasonal variation is particularly important for this region.

Land snails are among the most common fossil remains in the aeolian sequences in the Loess Plateau and are widely distributed in different ecological environments [4,11]. In the modern Loess Plateau, land snails are sensitive to seasonal climate and prefer to grow in different seasons and habitats according to their ecological tolerances $[11,12]$. Thus, snail shells can record seasonal climate information such as isotopic compositions of plants and rainfall during their shell's growth [13-18]. In recent years, carbon and oxygen isotope compositions of snail shells have been used to indicate seasonal climate, and many advances have been achieved [13-18].

Previous studies of land snails from the Loess Plateau have shown the $\delta^{13} \mathrm{C}$ of snail shells were closely related to the $\delta^{13} \mathrm{C}$ of plants during the snail's active season [15]. Gu et al. [16] considered that snails that grow in spring would ingest more $\mathrm{C}_{3}$ plants and present a more negative shell $\delta^{13} \mathrm{C}$. Conversely, summer growth would increase the proportion of $\mathrm{C}_{4}$ plants in their food and show a more positive $\delta^{13} \mathrm{C}$ value. For changes in $\delta^{18} \mathrm{O}$, Leng et al. [13] and Sun et al. [17] found that the abundance of ${ }^{18} \mathrm{O}$ in snail shells is dom- inantly controlled by the $\delta^{18} \mathrm{O}$ of rainwater during snail growth.

In the Loess Plateau, different snail species tend to grow under different seasonal climate conditions in either spring, summer or autumn. Since the duration of each season varies largely from the southeast to northwest [19] the length of snail growing season and relative abundance of $\mathrm{C}_{3}$ and $\mathrm{C}_{4}$ plants eaten also correspond with these changes [19-21]. Thus, it is possible to analyze the isotopic composition of fossil snail shells to provide a suitable interpretation for variation of seasonal length in different parts of the Loess Plateau.

In this study, we examined the $\delta^{13} \mathrm{C}$ and $\delta^{18} \mathrm{O}$ from two typical snail species, the cold-aridiphilous Pupilla aeoli and thermo-humidiphilous Punctum orphana. The snail shells were retrieved from 18 localities across the Loess Plateau to determine the relationship between their isotopic composition and the seasonal climate in which they lived. Using this data, we preliminarily estimated the length of the snail growing season of the last $75 \mathrm{ka}$ in the Xifeng region of the Loess Plateau.

\section{Materials and method}

\subsection{Modern land snail samples}

Eighteen modern land snail samples were collected along latitude $\sim 35^{\circ} \mathrm{N}$ from Niangziguan, Shanxi Province, in the eastern Loess Plateau, to Guanting, Qinghai Province, in the western Loess Plateau during May 2005 (Figure 1). The snail populations were obtained from different habitats

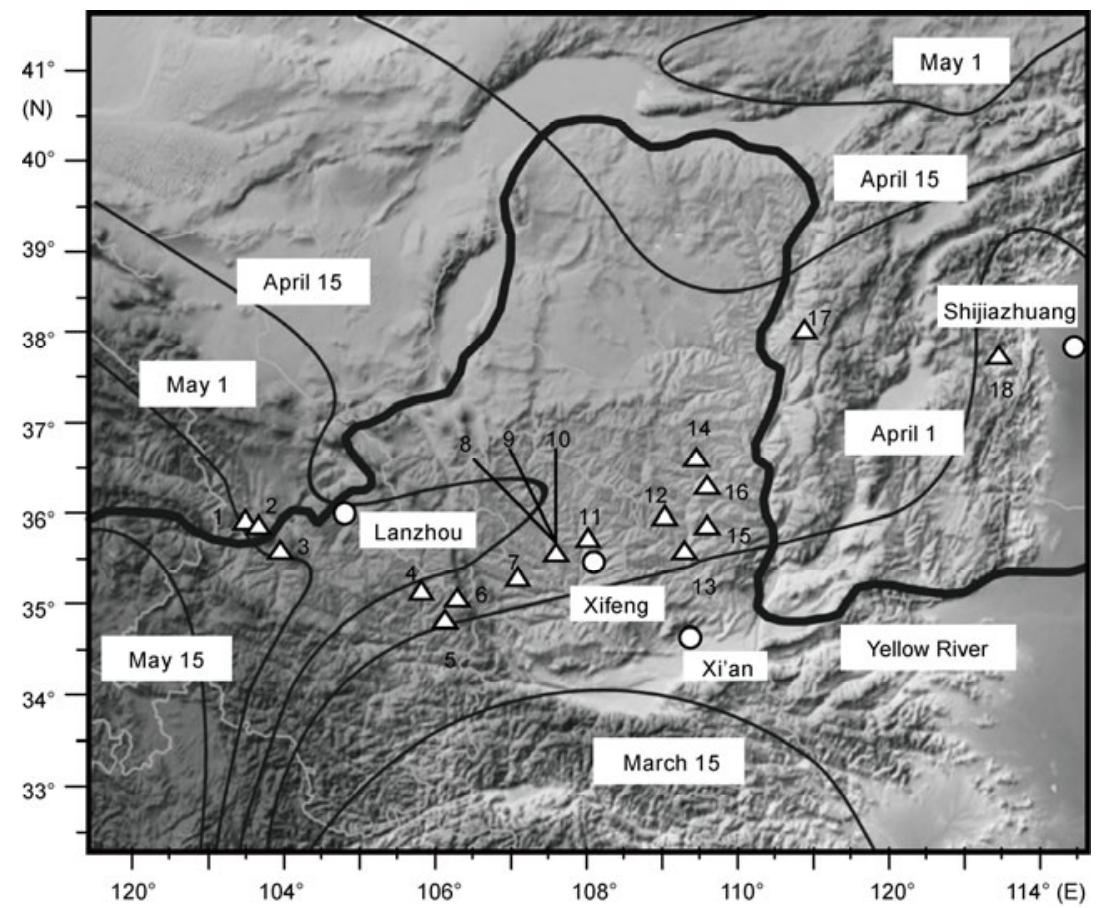

Figure 1 Location of this study's modern sampling sites (white triangles) and Xifeng loess sequence, and the beginning of spring in different regions of the Loess Plateau [19]. The numbers mean 18 sampling localities (see Table 1). 
including woodland, hill slopes and open ground under trees, grass, litter or leaves. All these localities were devoid of interference from human activity and were positioned using GPS. Every sample was collected within a $1 \mathrm{~m}^{2}$ radius following removal of surface litter, and the top $2-5 \mathrm{~cm}$ topsoil was also collected. Each of these samples weighed between 10 to $20 \mathrm{~kg}$. The soil samples were washed and sieved (mesh diameter of $0.5 \mathrm{~mm}$ ) in the field. In the lab, samples were further washed and dried. All snail shells collected were sorted and identified under a binocular microscope.

Our modern investigation spans $11^{\circ}$ of longitude and a range of more than $1000 \mathrm{~km}$ across the whole Loess Plateau (Figure 1). In the area covered, the arrival of spring is not synchronous, with a lag of approximately one month from the east to the west [19]. The arrival of spring in Niangziguan, Shanxi Province is in late March, while Guanting, Qinghai Province it is late April, about one month later than in Niangziguan (Figure 1). According to meteorological data of the past 50 years (data from China Meteorological Data Sharing Service System. http://cdc. cma.gov.cn/, similarly hereinafter), the durations of daily mean temperature higher than $10^{\circ} \mathrm{C}$ in Niangziguan and Guanting are $202 \pm 6 \mathrm{~d}$ and $162 \pm 7 \mathrm{~d}$, respectively (Table 1). Summer temperatures $\geqslant 22^{\circ} \mathrm{C}$ are about $71 \pm 13 \mathrm{~d}$ in Niangziguan and less than $30 \mathrm{~d}$ in Guanting [20] (see Table 1 and Figure 2).

Table 1 Seasonal length and stable isotopic data from modern $P$. aeoli and $P$. orphana shells from 18 sampling localities

\begin{tabular}{|c|c|c|c|c|c|c|c|c|c|c|c|c|c|c|}
\hline \multirow{2}{*}{ Locality } & \multirow{2}{*}{$\begin{array}{l}\text { Latitude } \\
\text { (N) }\end{array}$} & \multirow{2}{*}{$\begin{array}{l}\text { Longitude } \\
\text { (E) }\end{array}$} & \multicolumn{2}{|c|}{ Duration $(\mathrm{d})$} & \multicolumn{2}{|c|}{$\delta^{13} \mathrm{C}(\% o)$} & \multirow{2}{*}{$\begin{array}{c}\delta^{13} \mathrm{C} \\
\text { difference }\end{array}$} & \multirow{2}{*}{$\begin{array}{c}\text { Mean }^{a)} \\
\text { (absolute) }\end{array}$} & \multirow{2}{*}{$\mathrm{SD}$} & \multicolumn{2}{|c|}{$\delta^{18} \mathrm{O}(\%)$} & \multirow{2}{*}{$\begin{array}{c}\delta^{18} \mathrm{O} \\
\text { difference }\end{array}$} & \multirow{2}{*}{$\begin{array}{c}\text { Mean }^{\mathrm{a})} \\
\text { (absolute) }\end{array}$} & \multirow{2}{*}{ SD } \\
\hline & & & $\geqslant 10^{\circ} \mathrm{C}$ & $\overline{\text { Summer }}$ & P. aeoli & P. orphana & & & & P. aeoli & P. orphana & & & \\
\hline 1. Guanting & $35^{\circ} 52.2^{\prime}$ & $102^{\circ} 47.2^{\prime}$ & $162 \pm 7$ & $<30$ & -7.9 & -8.5 & 0.6 & & & 0.3 & -2.9 & 3.2 & & \\
\hline 2. Jishishan & $35^{\circ} 45.2^{\prime}$ & $102^{\circ} 48.5^{\prime}$ & $162 \pm 7$ & $<30$ & -8.8 & -9.1 & 0.3 & & & -1.8 & -3.3 & 1.5 & & \\
\hline 3. Sanshilipu & $35^{\circ} 26.9^{\prime}$ & $103^{\circ} 17.2^{\prime}$ & $162 \pm 7$ & $<30$ & -9.1 & -7.7 & -1.4 & 0.2 & 1.1 & -1.2 & -5.2 & 4 & 2.9 & 1.3 \\
\hline 4. Qin'an & $35^{\circ} 2.0^{\prime}$ & $105^{\circ} 27^{\prime}$ & $191 \pm 6$ & $47 \pm 16$ & -6.8 & -4.6 & -2.2 & & & -3.2 & -5.9 & 2.7 & & \\
\hline 5. Tianshui & $34^{\circ} 36.7^{\prime}$ & $105^{\circ} 54.5^{\prime}$ & $191 \pm 6$ & $47 \pm 16$ & -8.9 & -8 & -0.9 & & & -3.1 & -7 & 3.9 & & \\
\hline 6. Yongshou & $34^{\circ} 55.4^{\prime}$ & $106^{\circ} 3.5^{\prime}$ & $191 \pm 6$ & $47 \pm 16$ & -8.9 & -7.8 & -1.1 & 1.4 & 0.7 & -2.7 & -6 & 3.3 & 3.3 & 0.6 \\
\hline 7. Pingliang & $35^{\circ} 24.2^{\prime}$ & $107^{\circ} 5.1^{\prime}$ & $183 \pm 6$ & $41 \pm 14$ & -9.1 & -7.5 & -1.6 & & & -5.1 & -7 & 1.9 & & \\
\hline 8. Xifeng & $35^{\circ} 45.8^{\prime}$ & $107^{\circ} 41.1^{\prime}$ & $183 \pm 6$ & $41 \pm 14$ & -7.3 & -4.9 & -2.4 & & & -2 & -6.6 & 4.6 & & \\
\hline 9. Xifeng & $35^{\circ} 45.9^{\prime}$ & $107^{\circ} 41.1^{\prime}$ & $183 \pm 6$ & $41 \pm 14$ & -5.2 & -3.1 & -2.1 & & & -2.7 & -6.3 & 3.6 & & \\
\hline 10. Xifeng & $35^{\circ} 45.6^{\prime}$ & $107^{\circ} 41.2^{\prime}$ & $183 \pm 6$ & $41 \pm 14$ & -8.1 & -7.3 & -0.8 & 1.7 & 0.7 & -3.4 & -5.7 & 2.3 & 3.1 & 1.2 \\
\hline 11. Qingyang & $36^{\circ} 1.9^{\prime}$ & $108^{\circ} 10.0^{\prime}$ & $186 \pm 6$ & $45 \pm 14$ & -6.9 & -2.8 & -4.1 & & & -3.7 & -8.9 & 5.2 & & \\
\hline 12. zhangjiawan & $36^{\circ} 1.4^{\prime}$ & $108^{\circ} 53.9^{\prime}$ & $186 \pm 6$ & $45 \pm 15$ & -7.8 & -8 & 0.2 & & & -3.4 & -5.7 & 2.3 & & \\
\hline 13. Yijun & $35^{\circ} 25.5^{\prime}$ & $109^{\circ} 5.8^{\prime}$ & $196 \pm 7$ & $57 \pm 18$ & -8.2 & -7.9 & -0.3 & & & -1.4 & -5.5 & 4.1 & & \\
\hline 15. Luochuan & $35^{\circ} 52.7^{\prime}$ & $109^{\circ} 24.8^{\prime}$ & $196 \pm 7$ & $57 \pm 18$ & -7 & -5.4 & -1.6 & & & -2.9 & -7.3 & 4.4 & & \\
\hline 16. Yan'an & $36^{\circ} 34.6^{\prime}$ & $109^{\circ} 24.9^{\prime}$ & $188 \pm 6$ & $42 \pm 15$ & -7.7 & -7.5 & -0.2 & 1.2 & 1.6 & -3.7 & -6 & 2.3 & 3.6 & 1.2 \\
\hline 17. Baode & $38^{\circ} 1.2^{\prime}$ & $111^{\circ} 9.9^{\prime}$ & $184 \pm 6$ & $51 \pm 15$ & -7.9 & -6.2 & -1.7 & 1.7 & - & -3.6 & -6.7 & 3.1 & 3.1 & - \\
\hline 18. Niangziguan & $37^{\circ} 55.5^{\prime}$ & $113^{\circ} 55.1^{\prime}$ & $202 \pm 6$ & $71 \pm 13$ & -4.7 & -1.9 & -2.8 & 2.8 & - & -3.1 & -7.8 & 4.7 & 4.7 & - \\
\hline
\end{tabular}

a) Mean $\delta^{13} \mathrm{C}$ or $\delta^{18} \mathrm{O}$ differences of samples from every two degrees of longitude.
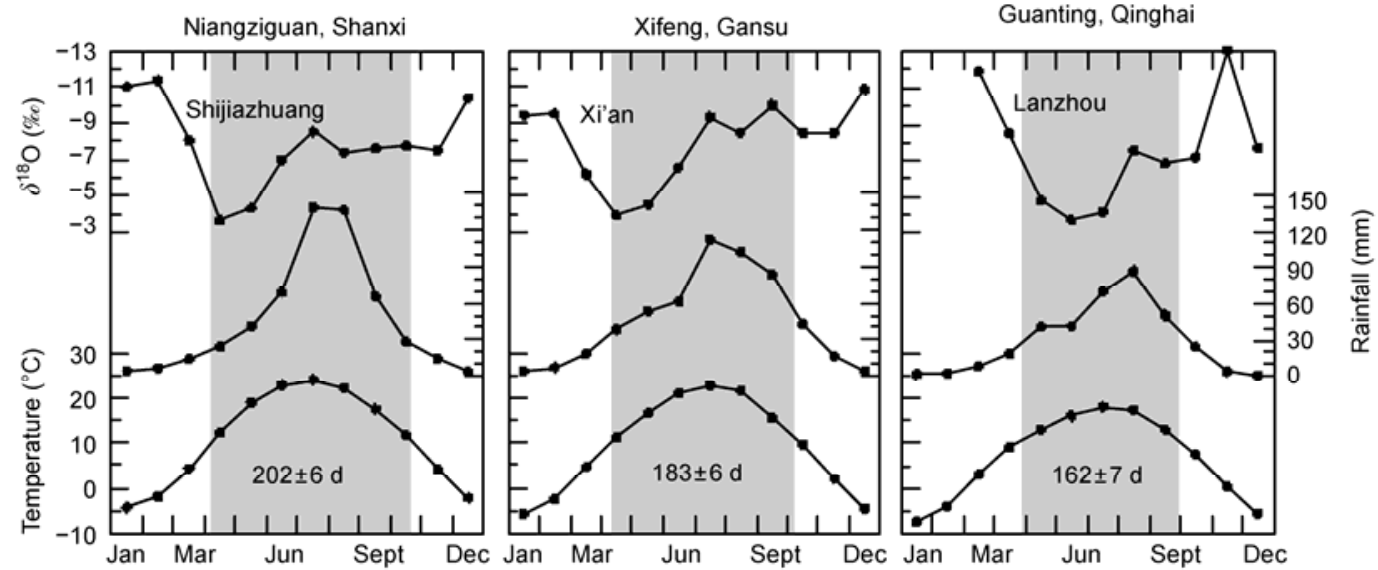

Figure 2 Monthly temperature and rainfall at Niangziguan in eastern Loess Plateau, Xifeng in central Loess Plateau, and Guanting in western Loess Plateau and their monthly rainfall $\delta^{18} \mathrm{O}(\%)$ from the nearest sites (Shijiazhuang, Xi' an and Lanzhou). The isotope data were taken from GNIP (http:// www-naweb.iaea.org/napc/ih/IHS_resources_gnip.html). Grey bands indicate the thermal range (i.e. temperature $\geqslant 10^{\circ} \mathrm{C}$ ) and the duration of snail activity $[20,22,23]$ 
In our study area, most of the rainfall occurs during thehot season from June to September, and the amount of rainfall decreases from east to west with respect to the Loess Plateau. The ${ }^{18} \mathrm{O}$ of rainfall is enriched in spring and depleted in summer, and the $\delta^{18} \mathrm{O}$ value of summer rainfall gradually becomes more positive towards the west (Figure 2 ). Vegetation also changes between these different climatic areas. For example, some $\mathrm{C}_{4}$ plants decrease from 150 species in the eastern semi-humid areas to 115 species in the western semi-arid areas [21].

Moreover, snail species and snail assemblages vary markedly with the change of hydrothermal conditions and ecological environments. The eastern parts of Loess Plateau are dominated by thermo-humidiphilous species, while the western parts are dominated by the cold-aridiphilous species $[11,12]$. Two different ecological species of cold-aridiphilous $P$. aeoli and thermo-humidiphilous $P$. orphana were selected to investigate the seasonal effects on their shell stable isotope composition among snail taxa. $P$. aeoli prefers relatively cold and dry conditions [4,11,12,24,25]. It is currently distributed in semiarid areas of northwest China [11]. In those areas the daily mean temperatures $\geqslant 10^{\circ} \mathrm{C}$ last for about 140 to $180 \mathrm{~d}$ and summer is normally shorter than $45 \mathrm{~d}$ [20]. $P$. orphana is prefers warm and humid conditions $[4,11,12,24,25]$. It is mainly found in the southern region of the Yellow River [11] where daily mean temperatures $\geqslant 10^{\circ} \mathrm{C}$ usually last for more than $200 \mathrm{~d}$ and the summer is longer than $60 \mathrm{~d}$ [20]. In all of the 18 localities examined, populations of $P$. aeoli and $P$. orphana were abundant. A total of 36 populations $(2 \times 18)$, each consisting of 15 to 30 adult snail shells, were subsequently selected for carbon and oxygen isotopic composition [15].

\subsection{Fossil land snail samples}

The Xifeng loess sequence $\left(35^{\circ} 46^{\prime} \mathrm{N}, 107^{\circ} 41^{\prime} \mathrm{E}\right)$ is located in the central part of the Loess Plateau (Figure 1). It is one of the most classic loess sections where a large number of research has been previously carried out [5,6,10,26-33]. Studies on fossil land snail assemblages since the last glacial are also well documented [32,33]. In the Xifeng area, the summer season is presently $\sim 40-50 \mathrm{~d}$ and winter $\sim 180 \mathrm{~d}$ [20]. Mean annual temperature and precipitation of this region is $\sim 9.3^{\circ} \mathrm{C}$ and $\sim 560 \mathrm{~mm}$ respectively. Over $60 \%$ of the rainfall is concentrated in the months June to September, with $\sim 20 \%$ precipitated during spring.

Since the last $75 \mathrm{ka}$, the Xifeng loess section shows a thickness of $12.2 \mathrm{~m}$. The upper $40 \mathrm{~cm}$ is a cultivated horizon with a boundary of $\sim 3$ ka BP [4]. Figure 3 shows the stratigraphy and magnetic susceptibility [6] since the last 75 $\mathrm{ka}$ and their correlations with the LR04 $\delta^{18} \mathrm{O}$ record [34]. Our time series was derived from Kukla et al. [5,6] with upper $12.2 \mathrm{~m}$ deposit covering $75.5 \mathrm{ka} \mathrm{BP}$.

From all the 122 samples during the last $75 \mathrm{ka}$, we obtained 115 populations of $P$. aeoli and 37 of $P$. orphana. The 15-30 adult shells from each population were selected for stable isotope analysis [15]. However, not all samples yielded sufficient shell weights for stable isotope analysis, particularly for $P$. orphana in the $\mathrm{L}_{1-5}$ and $\mathrm{L}_{1-1}$ units. When the amount of fossil shell was not enough for analysis, we combined neighboring samples.

\subsection{Isotopic methods}

The shells from both modern and fossil snails were first

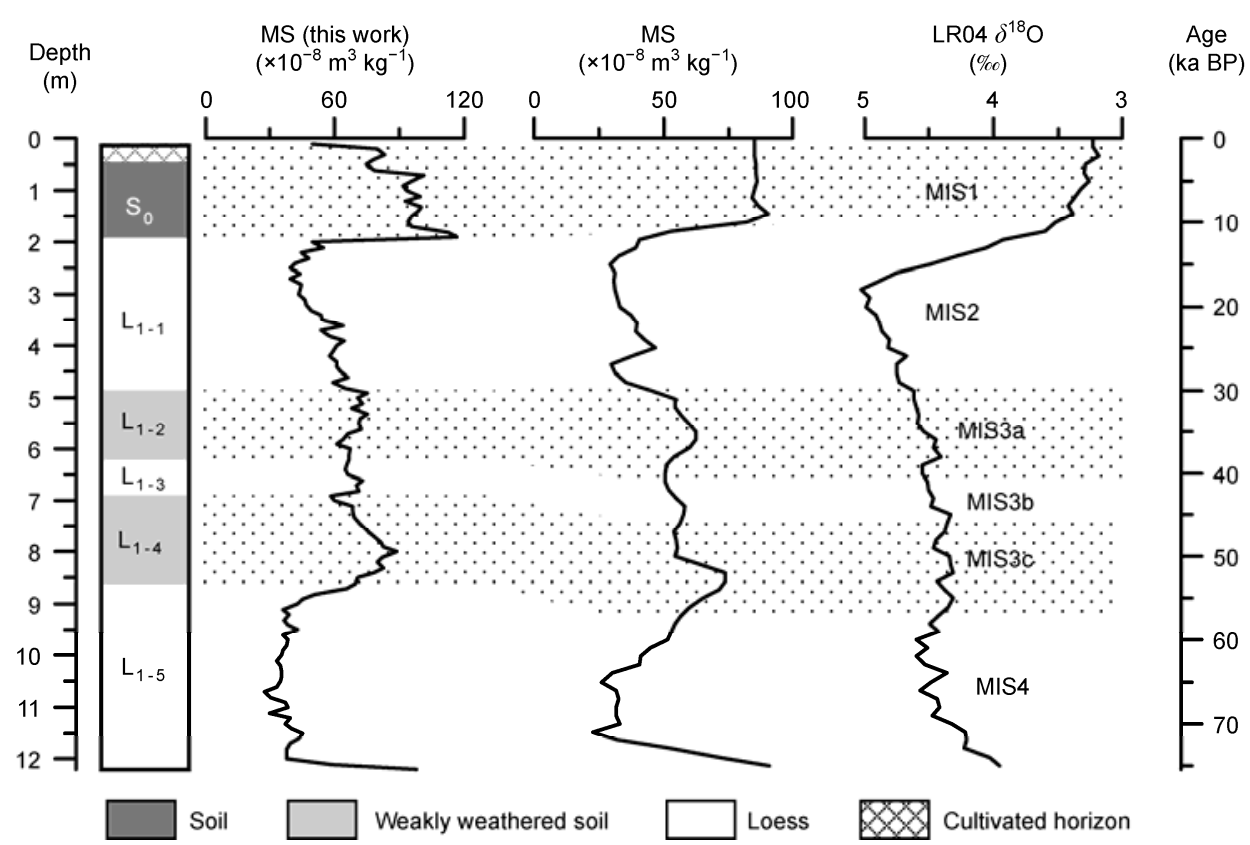

Figure 3 Stratigraphy and magnetic susceptibility (MS) [6] of the Xifeng loess-soil section since the last 75 ka and their correlation with the LR04 $\delta^{18} \mathrm{O}$ record [34]. 
cleaned in an ultrasonic bath and then gently crushed and placed in a bath of $10 \% \mathrm{H}_{2} \mathrm{O}_{2}$ for $24 \mathrm{~h}$ to remove any organic matter. After this treatment, the snail shells were ultrasonicated again, oven dried at $50^{\circ} \mathrm{C}$ and grinded into $\sim 100 \mu \mathrm{m}$ fractions. Under vacuum, the oxygen and carbon isotopic composition of the shell powder was measured from the $\mathrm{CO}_{2}$ released by overnight reaction with $100 \%$ $\mathrm{H}_{3} \mathrm{PO}_{4}$ at $25^{\circ} \mathrm{C}$ using a carbonate reaction device of Gas Bench-2 attached to a mass spectrometer. All samples were measured on a MAT253 gas mass spectrometer in the Key Laboratory of Cenozoic Geology and Environment, Institute of Geology and Geophysics, Chinese Academy of Sciences. Isotopic results are reported in conventional $\delta^{13} \mathrm{C}$ and $\delta^{18} \mathrm{O}$ notation in per mil versus V-PDB standard where:

$$
\delta^{13} \mathrm{C} \text { or } \delta^{18} \mathrm{O}(\%)=\left[\left(R_{\text {sample }} / R_{\text {standard }}\right)-1\right] \times 1000
$$

and $R={ }^{13} \mathrm{C} /{ }^{12} \mathrm{C}$ or ${ }^{18} \mathrm{O} /{ }^{16} \mathrm{O}$. The mean analytical reproducibility $(1 \sigma)$ was $0.1 \%$ and $\leqslant 0.2 \%$ or for carbon and oxygen respectively.

\section{Results}

\subsection{Stable carbon and oxygen isotope composition of modern land snail shells}

(1) Carbon isotope composition. From all modern populations analyzed, the mean $\delta^{13} \mathrm{C}$ of $P$. aeoli shells was $-7.6 \pm$ $1.3 \%$, ranging from $-9.1 \%$ o to $-4.7 \%$ o. For $P$. orphana shells, the mean $\delta^{13} \mathrm{C}$ was $-6.3 \pm 2.2 \%$, ranging from $-9.1 \%$ o to $-1.9 \%$ (Table 1, Figure 4(a)). P. aeoli shells were on average $1.3 \pm 1.0 \%$ o more depleted in ${ }^{13} \mathrm{C}$ than $P$. orphana shells. Furthermore, the depletion becomes gradually larger from the western to the eastern Loess Plateau as the $\delta^{13} \mathrm{C}$ difference between both snail species increases eastward. At the most eastern locality the depletion reached a maxima as snail growing season became much longer.

In modern snail populations, some localities have a similar longitude but different latitude (about 100-200 km away) (Figure 1). These different micro-environments (plateau or gully) also influence the $\delta^{13} \mathrm{C}$ values of snail shells, which cause a larger longitudinal variation in $\delta^{13} \mathrm{C}$ values (Figure 4(a)). To better understand the general tendency of the $\delta^{13} \mathrm{C}$ difference along the east-west climate gradient, we combined every two degrees of longitude as one unit and averaged their $\delta^{13} \mathrm{C}$ differences (Figure 4(c)). As a result, samples from the western part of the Loess Plateau where the season is shorter has the smallest $\delta^{13} \mathrm{C}$ difference of 0.2 $\pm 1.1 \%$, while in the eastern part where the growing season is longer, the largest difference in $\delta^{13} \mathrm{C}$ was up to $2.8 \%$.

(2) Oxygen isotope composition. The mean $\delta^{18} \mathrm{O}$ from $P$. aeoli shells was $-2.8 \pm 1.2 \%$, ranging from $-5.0 \%$ o to $0.3 \%$ o. The mean $\delta^{18} \mathrm{O}$ from $P$. orphana shells was $-6.2 \pm 1.4 \%$, ranging from $-8.9 \%$ to $-2.9 \%$ (Table 1, Figure 4(b)). The $\delta^{18} \mathrm{O}$ value of $P$. aeoli shells is on average $3.3 \pm 1.1 \%$ o more positive than the $P$. orphana shells. Similar to the $\delta^{13} \mathrm{C}$, the $\delta^{18} \mathrm{O}$ values from the $P$. aeoli shells becomes more positive than those from $P$. orphana shells from the west to the east plateau, and reaches a maximum at the furthest east. When we combined every two degrees of longitude into one unit and averaged the difference in $\delta^{18} \mathrm{O}$ (Figure 4(d)) the western part had the smallest value of $2.9 \pm 1.3 \%$. The highest value of $4.7 \%$ was found at the furthest east site.

\subsection{Isotopic composition of snail shells from the Xifeng loess sequence}

One hundred and fifteen populations of $P$. aeoli from the $\mathrm{L}_{1}-\mathrm{S}_{0}$ strata of the Xifeng loess section show variations in
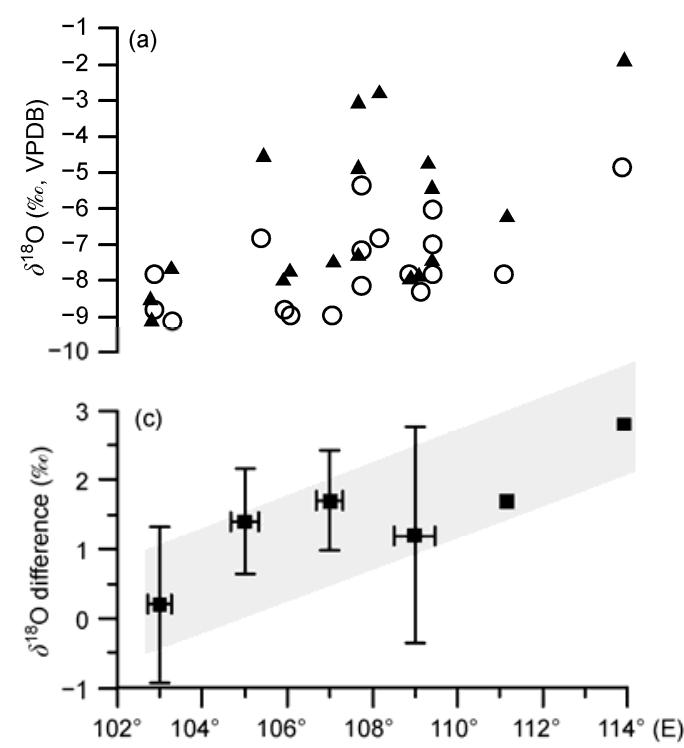
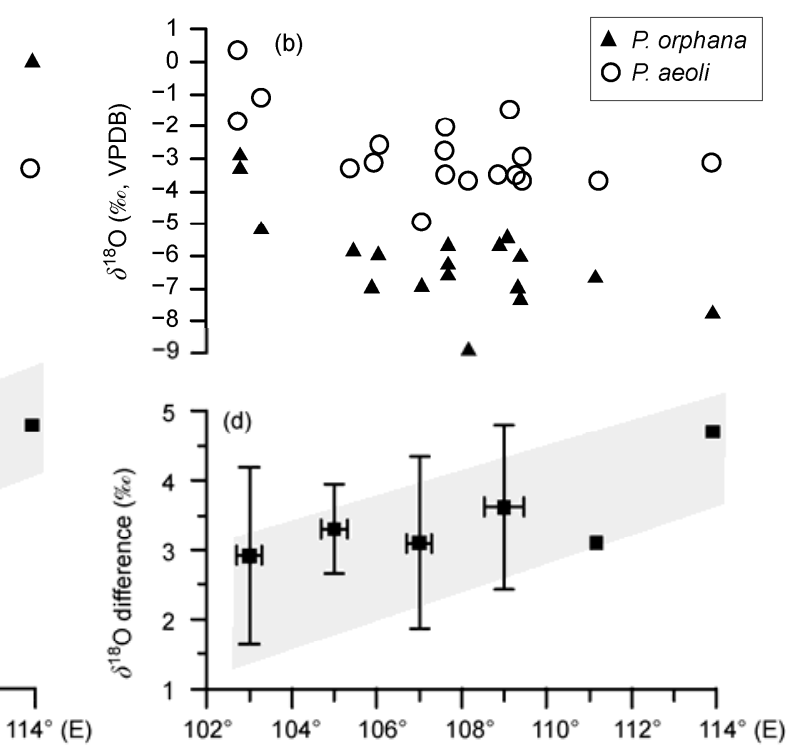

Figure 4 The $\delta^{13} \mathrm{C}$ (a) and $\delta^{18} \mathrm{O}$ (b) of modern land snail shells from this study and the variable $\delta^{13} \mathrm{C}(\mathrm{c})$ and $\delta^{18} \mathrm{O}(\mathrm{d})$ differences of both snail species (where samples from every $2^{\circ}$ of longitude were combined as 1 unit). 
shells isotope composition since the last $75 \mathrm{ka}$. Only 37 populations of $P$. orphana had sufficient weight for isotope measurement, mainly in the $S_{0}$ and the upper part of $\mathrm{L}_{1-1}$ sequence and only a few occurring in the $\mathrm{L}_{1-3}$ to $\mathrm{L}_{1-5}$ (Figure 5).

Generally, the fossil shells of $P$. aeoli are more negative in $\delta^{13} \mathrm{C}$ and more positive in $\delta^{18} \mathrm{O}$ compared with $P$. orphana. The $\delta^{13} \mathrm{C}$ values from $P$. aeoli shells ranged from $-6.4 \%$ o to $-8.3 \%$, while the $P$. orphana shells ranged from $-3.2 \%$ to $-6.8 \%$ (Figure 5). The $\delta^{18} \mathrm{O}$ values of $P$. aeoli shells were highly variable during the last $75 \mathrm{ka}$ with amplitudes up to $6 \%$, a maximum of $-3.1 \%$ and minimum of $-8.9 \%$. The $\delta^{18} \mathrm{O}$ values of $P$. orphana shells ranged from $-6.0 \%$ to $-8.1 \%$ o (Figure 5). Overall, the isotopic differences in both snail shells differ widely during four periods in particular (MIS 4, MIS 3c-3b, MIS 2 and MIS 1).

During MIS $4\left(\mathrm{~L}_{1-5}\right)$ the mean $\delta^{13} \mathrm{C}$ difference from both snail shells was $0.9 \pm 0.2 \%$ and the mean $\delta^{18} \mathrm{O}$ difference was $0.5 \pm 0.5 \%$. For MIS $3 \mathrm{c}-3 \mathrm{~b}\left(\mathrm{~L}_{1-4}-\mathrm{L}_{1-3}\right)$ the mean $\delta^{13} \mathrm{C}$ and $\delta^{18} \mathrm{O}$ differences were $2.5 \pm 0.4 \%$ and $1.6 \pm 0.8 \%$, respectively. At MIS $2\left(\mathrm{~L}_{1-1}\right)$ the mean $\delta^{13} \mathrm{C}$ and $\delta^{18} \mathrm{O}$ differences were $0.2 \%$ and $0.4 \%$, respectively.

During MIS $1\left(\mathrm{~S}_{0}\right)$ in the early Holocene (11-8 ka BP) the mean $\delta^{13} \mathrm{C}$ and $\delta^{18} \mathrm{O}$ differences were $1.3 \pm 0.5 \%$ and 2.2 $\pm 0.6 \%$, respectively. In the mid-Holocene (8-3 ka BP) these values were $2.6 \pm 0.7 \%$ and $2.1 \pm 1.4 \%$ o, respectively. For the late Holocene ( $<3 \mathrm{ka} \mathrm{BP})$, since the upper part of $\mathrm{S}_{0}$ was a cultivated horizon, it is not discussed. The largest differences in the $\delta^{13} \mathrm{C}$ and $\delta^{18} \mathrm{O}$ values appear during midHolocene (8-3 ka BP) followed by MIS 3. The smallest differences occurred during the glacial periods (MIS 4 and
MIS 2).

\section{Discussion}

\subsection{Seasonal implications inferred from the stable carbon and oxygen isotopic compositions in modern land snail shells}

(1) Carbon isotopic compositions and their relationship with seasonal vegetation. Laboratory controlled experiments carried out by DeNiro and Epstein [35] showed that there was no significant difference between the $\delta^{13} \mathrm{C}$ in land snail body tissues or their diet, but that their shells were on average enriched in ${ }^{13} \mathrm{C}$ by about $14.2 \%$. Land snails mainly feed on sprouts and tender leaves [11] thus the $\delta^{13} \mathrm{C}$ in land snail shells is, to a large extent, controlled by the relative abundance of $C_{3} / C_{4}$ plants eaten by the snails [14-16, 36-38]. Generally, $C_{3}$ plants require more water than $C_{4}$ plants, whereas $\mathrm{C}_{4}$ plants require higher temperatures than $\mathrm{C}_{3}$ plants [39]. Therefore, in the areas where four distinct seasons occur such as the Loess Plateau, $\mathrm{C}_{3}$ and $\mathrm{C}_{4}$ plants dominate during different seasons. For example, $\mathrm{C}_{3}$ plants mainly grow in spring and autumn, while $\mathrm{C}_{4}$ plants grow during the summer [39]. Moreover, $\mathrm{C}_{3}$ and $\mathrm{C}_{4}$ plants have different carbon isotope compositions with mean $\delta^{13} \mathrm{C}$ values of $-27 \%$ and $-13 \%$, respectively [40].

As mentioned above, $P$. aeoli shells from 18 localities across the Loess Plateau have more negative $\delta^{13} \mathrm{C}$ value than $P$. orphana, with the most negative value of $2.8 \%$ o. This indicates that $P$. aeoli might consume more $\mathrm{C}_{3}$ plants than $P$. orphana, which could be further interpreted as $P$.

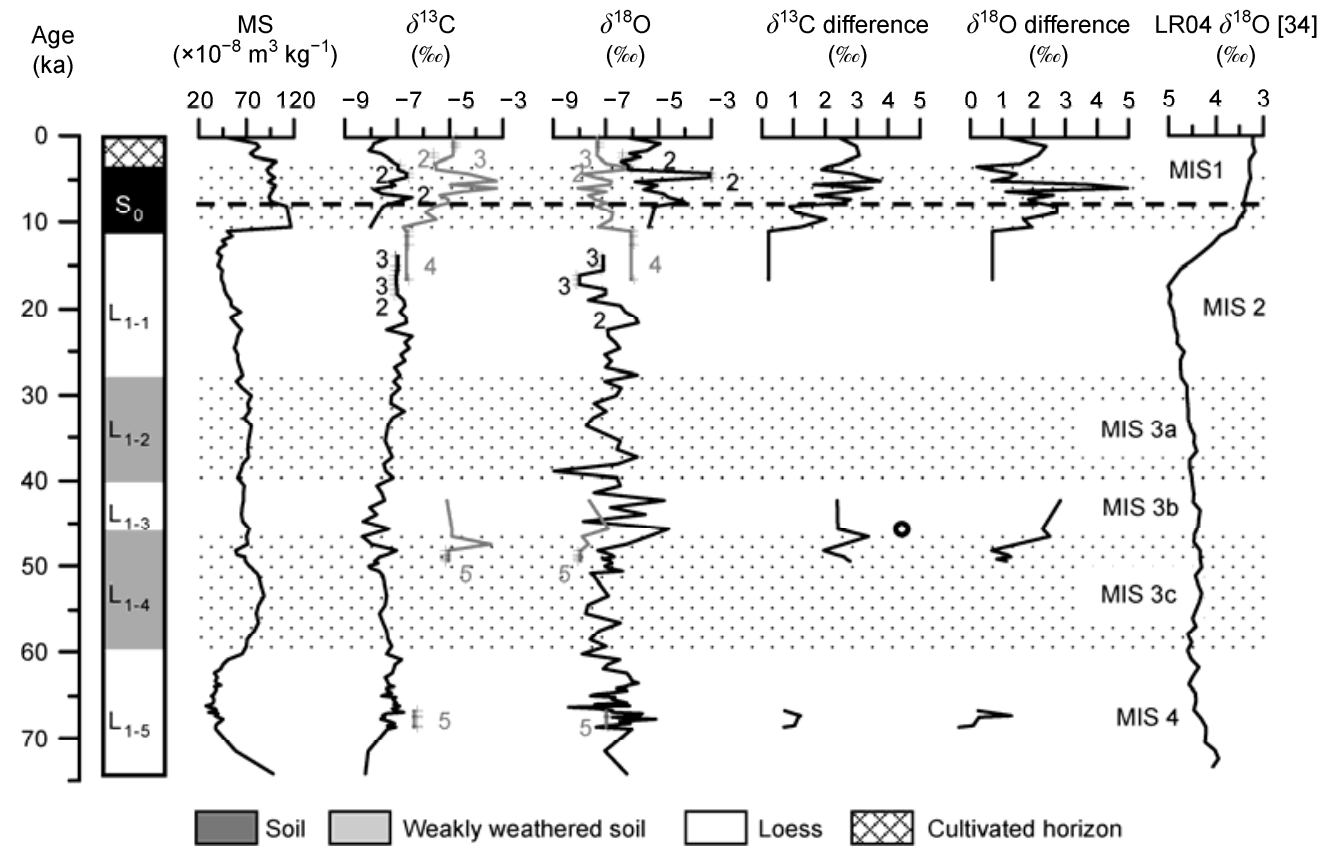

Figure 5 Variations in the $\delta^{13} \mathrm{C}$ and $\delta^{18} \mathrm{O}$ of $P$. aeoli (black line) and P. orphana (gray line) shells from the Xifeng section and their $\delta^{13} \mathrm{C}$ and $\delta^{18} \mathrm{O}$ differences. "+" means mixed populations, and the figure next to "+" means the number of mixed populations. 
aeoli preferring spring and autumn conditions when the climate is relatively cold and dry i.e. suitable for $\mathrm{C}_{3}$ plants. This is also in agreement with our field observations on living $P$. aeoli where they were found most active after rain in mid-May 2005 in the southeastern Loess Plateau and mid-September 2006 in the Liupanshan mountains. Conversely, the growing season of $P$. orphana prefers warm and humid summers in the Loess Plateau where it ingests more $\mathrm{C}_{4}$ plants. This is consistent with its living preference of warm-humid conditions. Furthermore, the $\delta^{13} \mathrm{C}$ of plants, particularly $\mathrm{C}_{3}$ plants, are also influenced by climatic factors $[41,42]$. These include temperature, precipitation and sunlight length. Therefore, plants growing in warm-humid summers may present more negative $\delta^{13} \mathrm{C}$ than those growing during the cold-arid spring [43]. However, these are not the main factors that cause the $\delta^{13} \mathrm{C}$ of $P$. aeoli shells to be more negative than $P$. orphana, as $P$. aeoli prefers cold and arid condition compared with $P$. orphana $[11,12]$. Thus, the $\delta^{13} \mathrm{C}$ of land snail shells most likely reflects the composition of local vegetation (i.e., $\mathrm{C}_{3}$ vs. $\mathrm{C}_{4}$ ) of snail food whilst providing key information on the snails' main growing season.

(2) Oxygen isotopic compositions and its relation to seasonal rainfall. The $\delta^{18} \mathrm{O}$ of land snail shells reflects the $\delta^{18} \mathrm{O}$ of body fluid when the shell is precipitated whilst the body fluid in snails are directly or indirectly related to rainfall $[16,17,44-47]$. Therefore, the $\delta^{18} \mathrm{O}$ of land snail shells can be used to infer rainfall [13,17,44-47]. In addition, the $\delta^{18} \mathrm{O}$ of land snail shells has a negative correlation with temperature and humidity during shell formation [23,48]. In the Loess Plateau, the $\delta^{18} \mathrm{O}$ value of rainfall is more negative in summer than in spring (Figure 2). Moreover, a large amount of rainfall occurs during the hot season which makes the summer more humid than spring. Thus, snails growing in spring such as $P$. aeoli present more positive $\delta^{18} \mathrm{O}$ values than those growing in the summer [16]. In our modern population $P$. aeoli shows more positive $\delta^{18} \mathrm{O}$ values than $P$. orphana. This would indicate that $P$. aeoli grow during the spring and $P$. orphana during the summer, which is consistent with their $\delta^{13} \mathrm{C}$ values and our field observations.

(3) Carbon and oxygen isotopic compositions and their relationship with seasonal length. Land snails are very sensitive to temperature and humidity. When the air temperature is above $\sim 25-27^{\circ} \mathrm{C}$ or below $\sim 10^{\circ} \mathrm{C}$, snails will enter a dormant phase [22,23,49]. Many species can only survive and grow within certain ranges of temperature and humidity and thus, snail assemblages from different seasonal climatic regions have their own dominant species. For example, $P$. aeoli is found in abundance in the west Loess Plateau, while $P$. orphana occurs abundantly in the east Plateau $[11,12]$. Both isotopic differences in the shells of $P$. aeoli and $P$. orphana are shown in Figure 4. It shows a gradual increase in $\delta^{13} \mathrm{C}$ and $\delta^{18} \mathrm{O}$ from the western to eastern Loess Plateau, which might be largely contributed by the change in seasonal climate across our study area.
At present the duration of daily mean temperatures $\geqslant 10^{\circ} \mathrm{C}$ at Niangziguan, Shanxi Province and Guanting, Qinghai Province are $202 \pm 7 \mathrm{~d}$ and $162 \pm 6 \mathrm{~d}$, respectively [20] (Table 1, Figure 2). This means that the snail growing season is shortened by about $40 \mathrm{~d}$ in the west compared with the east of the Loess Plateau. As the length of growing season reduces, $P$. aeoli in the west delays its activity and grows in early summer which is closer to the growing season of $P$. orphana. This may be the main reason for the small $\delta^{13} \mathrm{C}$ difference (similar diet) of both snail species in the western Loess Plateau.

According to the relationship from the $\delta^{13} \mathrm{C}$ difference of modern snail shells and the length of snail growing season (Table 1, Figure 6(a) and (c)), every $1 \%$ o difference in $\delta^{13} \mathrm{C}$ equates $\sim 15 \mathrm{~d}$ longer or shorter for the snail growing season.

The difference in $\delta^{18} \mathrm{O}$ from both snail species might be also related to seasonal climate. Isotopic data of rainfall shows that the $\delta^{18} \mathrm{O}$ in summer (June to August) rainfall at Niangziguan in the eastern Loess Plateau is $-7.6 \pm 0.7 \%$, whilst in spring (April and May) it is $-3.9 \pm 0.5 \%$ o. The difference $\delta^{18} \mathrm{O}$ from rainfall between the summer and spring is about 3.7\%o. During the summer (July and August) and spring (May and June) at Guanting in the western Loess Plateau, the $\delta^{18} \mathrm{O}$ of the rainfall is $-5.4 \pm 1.9 \%$ and $-4.9 \pm$ $0.7 \%$, respectively. Seasonal differences in Guanting are only $\sim 0.5 \%$ o. Thus, the seasonal difference in $\delta^{18} \mathrm{O}$ from rainfall may be due to another cause that contributes to the smaller difference in $\delta^{18} \mathrm{O}$ in both snail species from western part, and larger difference in eastern part of the Loess Plateau.

Furthermore, temperature and humidity between seasons also varies greatly from the eastern to western Loess Plateau. The temperature difference between the summer and spring is up to $11^{\circ} \mathrm{C}$ in the east, and more than $50 \%$ less $\left(\sim 5^{\circ} \mathrm{C}\right)$ in the west. The rainfall difference between summer and spring is $82 \mathrm{~mm}$ per month in the east, and drops to only 37 $\mathrm{mm}$ per month in the west (Figure 2). Seasonal differences in the $\delta^{18} \mathrm{O}$ from rainfall, temperature and humidity are remarkably larger in the east than in the west. Thus, the longer seasonal length and greater seasonal difference causes a larger difference in $\delta^{18} \mathrm{O}$ in both snail species in the east. According to our calculations, every $1 \%$ o difference in $\delta^{18} \mathrm{O}$ represents $\sim 19 \mathrm{~d}$ longer or shorter for snail growth (Figure 6(b) and (d)). Therefore, the $\delta^{13} \mathrm{C}$ and $\delta^{18} \mathrm{O}$ differences from both snail shells can be used to indicate the duration of the snail growing season. Moreover, the $\delta^{13} \mathrm{C}$ difference is more closely related to snail growing season and has greater potential than $\delta^{18} \mathrm{O}$ for determining the length of the growing season (Figure 6). However, it should be noted that the spatial distribution of our modern snail samples are limited and further extensive investigations are needed. Despite this, we interpret that the isotopic difference of both snail species could indicate the length of growing season and be used to infer their past growing seasons based on the isotope records of fossil land snail shells. 

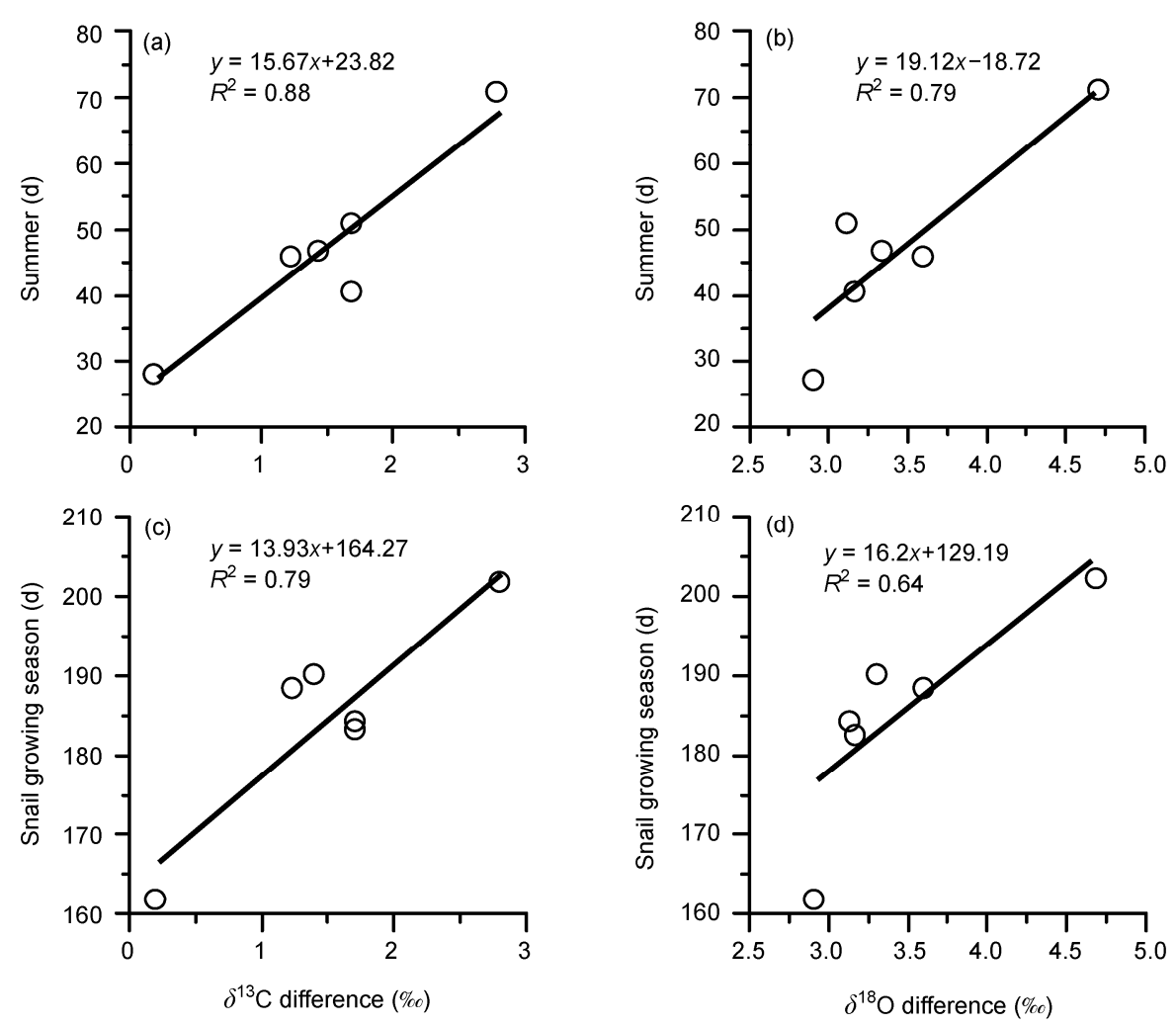

Figure 6 Relationship between mean $\delta^{13} \mathrm{C}$ and $\delta^{18} \mathrm{O}$ differences along with the durations of summer (a), (b) and snail growing season (c), (d). Samples from every $2^{\circ}$ of longitude were combined into 1 unit.

\subsection{Seasonal characteristics of cold and warm periods during the last $75 \mathrm{ka}$}

As shown in Figure 5, the $\delta^{13} \mathrm{C}$ of $P$. aeoli shells during the last $75 \mathrm{ka}$ changed slightly, while the $\delta^{18} \mathrm{O}$ shows a larger variability. During the Holocene and MIS 3c-3b, P. aeoli has slightly negative $\delta^{13} \mathrm{C}$ values and relatively positive $\delta^{18} \mathrm{O}$ values compared with the colder glacial periods of MIS 4 and 2. One explanation could be that this species was living in spring during the warm periods of the Holocene and MIS 3, and forced to grow in summer during the colder glacial periods of MIS 2 and 4. This could also be related to the ingestion of more $\mathrm{C}_{4}$ plants and summer rainfall during MIS 4 and 2. A previous study of $\mathrm{C}_{3}$ plants indicated that more positive $\delta^{13} \mathrm{C}$ values occurred during cold periods than warm periods [43] which might be another interpretation for the higher $\delta^{13} \mathrm{C}$ values during MIS 4 and 2. On the other hand, $P$. orphana shells present more positive in $\delta^{13} \mathrm{C}$ and more negative in $\delta^{18} \mathrm{O}$ during warm periods than during cold periods. This could be due to higher abundances of $\mathrm{C}_{4}$ plants [50] and more negative $\delta^{18} \mathrm{O}$ values of summer rainfall during the warm periods [51].

Based on the relationship between the isotopic differences in the two modern snail species from the Loess Plateau and their growing season (Figure 6(c) and (d)), the length of the growing season during the past $75 \mathrm{ka}$ can be estimated. It should be noted that this estimate was mostly based on the difference in the $\delta^{13} \mathrm{C}$ of the snail shells rather than the $\delta^{18} \mathrm{O}$ as the latter is affected by too many factors $[13,17,23,44-48]$. The error of estimated days was calculated in terms of the error of mean $\delta^{13} \mathrm{C}$ difference. As shown in Figure 5, the $\delta^{13} \mathrm{C}$ differences are lower during MIS 4 and 2, reaching $\sim 0.0 \%$ at MIS 2. A similar phenomenon in modern land snail populations occurred in the western Loess Plateau. During MIS 4 and 2, the mean $\delta^{13} \mathrm{C}$ differences were $0.9 \pm 0.2 \%$ and $0.2 \%$, respectively. Hence, the length of snail growing season at MIS 4 and 2 was estimated to be $\sim 160 \pm 3 \mathrm{~d}$, which is $\sim 20 \mathrm{~d}$ shorter than present day. Moreover, the growing season during MIS 2 was shorter than MIS 4.

During MIS 3c-3b, the climate in the Loess Plateau was relatively moderate [32]. At this stage, the mean $\delta^{13} \mathrm{C}$ difference was $2.5 \pm 0.4 \%$, which was larger than modern values from the Xifeng region and close to the value recorded from Niangziguan in the eastern Loess Plateau. The snail growing season during MIS 3 was estimated to be about 190 $\pm 6 \mathrm{~d}$.

The mean $\delta^{13} \mathrm{C}$ difference during the early Holocene (11-8 ka BP) is $1.3 \pm 0.5 \%$ which equated $\sim 170-180 \mathrm{~d}$ for snails growing at that time in the Xifeng area, a little shorter than present. During the mid-Holocene (8-3 ka BP), a difference of $2.6 \pm 0.7 \%$ occurred, implying about $200 \pm 10 \mathrm{~d}$ for snail growth. This is $20 \mathrm{~d}$ longer than the modern growing season and $40 \mathrm{~d}$ longer than MIS 4 and 2. The cli- 
mate during this period was probably similar to that of Niangziguan today.

The stable isotopic difference in both snail species suggests that the length of the snail growing season varied greatly since the last $75 \mathrm{ka}$. The longest growing season occurred in mid-Holocene, followed by MIS 3. We found the Last Glacial Maximum (MIS 2) had the shortest growing season, followed by MIS 4. The length of the biological growing season indicates that the duration time of the summer monsoon impact in the Loess Plateau, which might promote further understanding of the processes of paleoclimatic change, and thus needs to be studied further.

It should be noted out that the low abundance of $P$. orphana shells in some parts of the Xifeng loess section hindered us from obtaining a continuous isotope record and thus further information about seasonal climate changes during the last glacial period. Our empirical formulas (Figure 6) are mainly based on the limited data we obtained. Accurate quantification of the growing season length requires further work.

\section{Conclusion}

A study on the $\delta^{13} \mathrm{C}$ and $\delta^{18} \mathrm{O}$ differences between modern cold-aridiphilous $P$. aeoli and thermo-humidiphilous $P$. orphana from the Loess Plateau suggests that isotopic differences between both snail species has great potential to indicate seasonal length. Every $1 \%$ difference in $\delta^{13} \mathrm{C}$ from both snail species equates to $\sim 15 \mathrm{~d}$ longer or shorter for snail growing season, while for $\delta^{18} \mathrm{O}$ it is $\sim 19 \mathrm{~d}$.

The mean difference in $\delta^{13} \mathrm{C}$ from both $P$. aeoli and $P$. orphana shells was used to estimate the length of the snail growing season in the Xifeng area during the last $75 \mathrm{ka}$. The period during mid-Holocene $(8-3 \mathrm{ka})$ had the longest growing time (about $200 \pm 10 \mathrm{~d}$ ), which was $\sim 20 \mathrm{~d}$ longer than present. The second longest growing time was during MIS 3, $\sim 190 \pm 6$ d. Stages during the last glacial periods (MIS 4 and 2) held the shortest growing times $(\sim 160 \pm 3 \mathrm{~d})$, which is $\sim 40 \mathrm{~d}$ shorter than the mid-Holocene.

This work was supported by the National Basic Research Program of China (2010CB950204), Strategic Priority Research Program of the Chinese Academy of Sciences (XDA05120203) and the National Natural Science Foundation of China (40972119 and 40730104). The authors are grateful to Li Fengjiang, Li Quan and Xu Deke for field assistance and Wang Xu for his support in stable isotope analysis. We also sincerely thank Lü Houyuan for helpful discussions.

1 Milankovitch M. Kanon der Erdbestrahlung und seine Anwendung auf das Eiszeitenproblem. Belgrade: Royal Serbian Academy Special Publications, 1941. 1-633

2 Zhang J C, Lin Z G. Climate of China. New York: John Wiley \& Sons, 1992. 1-367

3 Zhang B K. The duration of four seasons in China (in Chinese). Acta Geograph Sin, 1934, 1: 1-18
4 Liu T S. Loess and the Environment. Beijing: China Ocean Press, 1985. 1-251

5 Kukla G, An Z S. Loess stratigraphy in Central China. Palaeogeogr Palaeoclimatol Palaeoecol, 1989, 72: 203-225

6 Kukla G, An Z S, Melice J L, et al. Magnetic susceptibility record of Chinese Loess. Trans Roy Soc Edinburgh: Earth Sci, 1990, 81: 263288

7 An Z S, Kukla G J, Porter S C, et al. Magnetic-susceptibility evidence of monsoon variation on the Loess Plateau of central China during the last 130,000 years. Quat Res, 1991, 36: 29-36

8 Xiao J L, Porter S C, An Z S, et al. Grain-size of quartz as an indicator of winter monsoon strength on the loess plateau of central China during the last 130000-yr. Quat Res, 1995, 43: 22-29

9 An Z S, Kukla G L, Porter S C, et al. Late Quaternary dust flow on the Chinese Loess Plateau. Catena, 1991, 18: 125-132

10 Guo Z T, Liu T S, Fedoroff N, et al. Climate extremes in Loess of China coupled with the strength of deep-water formation in the North Atlantic. Glob Planet Change, 1998, 18: 113-128

11 Chen D N, Gao J X. Economic Fauna Sinica of China-Terrestrial Mollusca (in Chinese). Beijing: Science Press, 1987. 1-186

12 Wu N Q, Li F J. Terrestrial mollusk fossils from Chinese loess sequence and their paleoenvironmental significance (in Chinese). Quat Sci, 2008, 28: 831-840

13 Leng M J, Heaton T H E, Lamb H F, et al. Carbon and oxygen isotope variations within the shell of an African land snail (Limicolaria kambeul chudeaur Germain): A high-resolution record of climate seasonality? Holocene, 1998, 8: 407-412

14 Balakrishnan M, Yapp C J, Theler J L, et al. Environmental significance of ${ }^{13} \mathrm{C} /{ }^{12} \mathrm{C}$ and ${ }^{18} \mathrm{O} /{ }^{16} \mathrm{O}$ ratios of modern land-snail shells from the southern great plains of North America. Quat Res, 2005, 63: $15-30$

15 Liu Z X, Gu Z Y, Wu N Q, et al. Diet control on carbon isotopic composition of land snail shell carbonate. Chin Sci Bull, 2007, 52: 388-394

$16 \mathrm{Gu}$ Z Y, Liu Z X, Xu B, et al. Stable carbon and oxygen isotopes in land snail carbonate shells from a last glacial loess sequence and their implications of environmental changes (in Chinese). Quat Sci, 2009, 29: 13-22

17 Sun X H, Gu Z Y, Xu B. Oxygen isotopic variations in the shells collected monthly from a live species of land snails at local in Zhenjiang, Jiangsu Province, China (in Chinese). Quat Sci, 2009, 29: 976-980

18 Colonese A C, Zanchetta G, Dotsika E, et al. Early-middle Holocene land snail shell stable isotope record from Grotta di Latronico 3 (southern Italy). J Quaternary Sci, 2010, 25: 1347-1358

19 Lin Z G. Climate of China (in Chinese). Beijing: China Meteorological Press, 1987. 24-34

20 Qian L Q. Climate of Loess Plateau (in Chinese). Beijing: China Meteorological Press, 1991. 30-54

21 Yin L J, Li M R. A study on the geographic distribution and ecology of $\mathrm{C}_{4}$ plants in China I. $\mathrm{C}_{4}$ plant distribution in China and their relation with regional climatic condition (in Chinese). Acta Ecol Sin, 1997, 17: 350-363

22 Cowie R H. The life-cycle and productivity of the land snail Theba posana (Mollusca: Helicidae). J Animal Ecol, 1984, 53: 311-325

23 Balakrishnan M, Yapp C J. Flux balance models for the oxygen and carbon isotope compositions of land snail shells. Geochim Cosmochim Acta, 2004, 68: 2007-2024

24 Yen T C. Die Chinesischen Land-und Süßwasser-Gastropoden des Natur-Museums Senckenberg. Abhandlumgen der Senckenbergischen Naturforschenden Gesellschaft, 1939, 444: 1-235

25 Wu N Q, Rousseau D D, Liu T S. Land mollusk records from the Luochuan loess sequence and their paleoenvironmental significance. Sci China Ser D-Earth Sci, 1996, 39: 494-502

26 Liu X M, Rolph T, Bloemendal J, et al. Quantitative estimates of palaeoprecipitation at Xifeng, in the Loess Plateau of China. Palaeogeogr Palaeoclimatol Palaeoecol, 1995, 113: 243-248

27 Lu H Y, An Z S. Paleoclimatic significance of grain-size composition of loess-paleosol deposit in Chinese Loess Plateau. Sci China Ser 
D-Earth Sci, 1998, 41: 626-631

28 Guo Z T, Biscaye P, Wei L Y, et al. Summer monsoon variations over the last 1.2 Ma from the weathering of loess-soil sequences in China. Geophys Res Lett, 2000, 27: 1751-1754

29 Jahn B, Gallet S, Han J. Geochemistry of the Xining, Xifeng and Jixian sections, Loess Plateau of China: Eolian dust provenance and paleosol evolution during the last $140 \mathrm{ka}$. Chem Geol, 2001, 178: $71-94$

30 Wu N Q, Chen X Y, Rousseau D D, et al. Climatic conditions recorded by terrestrial mollusc assemblages in the Chinese Loess Plateau during marine Oxygen Isotope Stages 12-10. Quat Sci Rev, 2007, 26: 1884-1896

31 Wu B, Wu N Q. Paleoenvironmental study of $\mathrm{S}_{5}$ paleosol formation: Based on mollusk fossil evidence (in Chinese). Quat Sci, 2008, 28: 901-908

32 Chen X Y, Wu N Q. Relatively warm-humid climate recorded by mollusk species in the Chinese Loess Plateau during MIS 3 and its possible forcing mechanism (in Chinese). Quat Sci, 2008, 28: 154161

33 Chen X Y. Terrestrial mollusk record from the Xifeng loess sequence in the Chinese Loess Plateau during the past $500 \mathrm{ka}$ and its implications for paleoenvironmental evolution (in Chinese). Dissertation for the Doctoral Degree. Beijing: Institute of Geology and Geophysics, Chinese Academy of Sciences, 2008. 24-78

34 Lisiecki L E, Raymo M E. A Pliocene-Pleistocene stack of 57 globally distributed benthic $\delta^{18} \mathrm{O}$ records. Paleoceanography, 2005, 20: PA1003

35 DeNiro M J, Epstein S. Influence of diet on the distribution of carbon isotopes in animals. Geochim Cosmochim Acta, 1978, 42: 495-506

36 Goodfriend G A, Magaritz M. Carbon and oxygen isotope composition of shell carbonate of desert land snails. Earth Planet Sci Lett, 1987, 86: $377-388$

37 Stott L D. The influence of diet on the $\delta^{13} \mathrm{C}$ of shell carbon in the pulmonate snail Helix aspersa. Earth Planet Sci Lett, 2002, 195: 249-259

38 Metref S, Rousseau D D, Bentaleb I, et al. Study of the diet effect on $\delta^{13} \mathrm{C}$ of shell carbonate of the land snail Helix aspersa in experi- mental conditions. Earth Planet Sci Lett, 2003, 211: 381-393

39 Long S P. Environmental responses. In: Sage R F, Monson R K, eds. $\mathrm{C}_{4}$ Plant Biology. San Diego: Academic Press, 1999. 215-249

40 Ehleringer J R. Implications of quantum yield differences to the distributions of $C_{3}$ and $C_{4}$ grasses. Oecologia, 1978, 31: 255-267

41 Stuiver M, Braziunas T F. Tree cellulose ${ }^{13} \mathrm{C} /{ }^{12} \mathrm{C}$ isotope rations and climate change. Nature, 1987, 328: 58-60

42 Farquhar G D, Ehleringer J R, Hubick K T. Carbon isotope discrimination and photosynthesis. Ann Rev Plant Physio, 1989, 40: 503-537

43 Wang G A, Han J M, Liu D S. The carbon isotope composition of $\mathrm{C}_{3}$ herbaceous plants in loess area of northern China. Sci China Ser D-Earth Sci, 2003, 46: 1069-1076

44 Lécolle $\mathrm{P}$. The oxygen isotope composition of land snail shells as a climatic indicator: Applications to hydrogeology and paleoclimatology. Chem Geol: Isot Geosci, 1985, 58: 157-181

45 Goodfriend G A, Magaritz M, Gat J R. Stable isotope composition of land snail body water and its relation to environmental water and shell carbonate. Geochim Cosmochim Acta, 1989, 53: 3215-3221

46 Zanchetta G, Leone G, Fallick A E, et al. Oxygen isotope composition of living land snail shells: Data from Italy. Palaeogeogr Palaeoclimatol Palaeoecol, 2005, 223: 20-33

47 Kehrwald N M, McCoy W D, Thibeault J, et al. Paleoclimatic implications of the spatial patterns of modern and LGM European land-snail shell $\delta^{18} \mathrm{O}$. Quat Res, 2010, 74: 166-176

48 Yapp C J. Oxygen and carbon isotope measurements of land snail shell carbonate. Geochim Cosmochim Acta, 1979, 43: 629-633

49 Chen D N, Zhang J Q. Fauna Sinica. Invertebrata (Vol. 37). Mullusca, Gastripoda, Stylommataphora Bradybaenidae (in Chinese). Beijing: Science Press, 2004. 20-27

$50 \mathrm{Gu}$ Z Y, Liu Q, Xu B, et al. Climate as the dominant control on $\mathrm{C}_{3}$ and $\mathrm{C}_{4}$ plant abundance in the Loess Plateau: Organic carbon isotope evidence from the last glacial-interglacial loess-soil sequences. Chin Sci Bull, 2003, 48: 1271-1276

51 Wang Y J, Cheng H, Edwards R L, et al. A high-resolution absolutedated Late Pleistocene monsoon record from Hulu Cave, China. Nature, 2001, 294: 2345-2348

Open Access This article is distributed under the terms of the Creative Commons Attribution License which permits any use, distribution, and reproduction in any medium, provided the original author(s) and source are credited. 